\title{
Comparison of 2 techniques for monitoring vegetation on military lands
}

\author{
C.W. PROSSER ${ }^{1}$, K.M. SKINNER, AND K.K. SEDIVEC
}

Authors are ecologist, National Park Service, 315 2nd Ave., Medora, N.D. 58645; assistant professor, Department of Biology, University of Nebraska at Kearney, Kearney, Neb. 68849; and extension rangeland specialist, Animal and Range Sciences Department, North Dakota State University, Fargo, N.D. 58105. At the time this manuscript was submitted, Prosser was an ecologist at the Northern Plains Agricultural Research Laboratory, Sidney, Mont. 59270.

\begin{abstract}
The U.S. Army is responsible for preparing a well-trained combat force while maintaining the ecological diversity and integrity of the lands it manages. The ability to efficiently collect data that accurately capture plant community diversity and percent composition is imperative to proper monitoring and land management of military lands. To ensure that the dual goals of military training and land stewardship are met on an army-wide basis, the U.S. Army Land Condition-Trend Analysis (LCTA) Program was developed. The LCTA Program specifies the Army's standard methodology for the collection, analysis, and reporting of natural resource data used for land inventory and monitoring. However, the LCTA sampling technique was developed in Colorado and Texas and little information is available on whether these methods are suitable for vegetation inventory and monitoring in other grassland ecosystems. This study compares LCTA measures of species richness and composition with quadrat sampling in the transitional area between the tall- and mixed-grass prairies of Camp Gilbert C. Grafton (South Unit) in North Dakota. Species richness was 67\% higher when sampling with quadrats than using the LCTA technique, suggesting that LCTA samples did not detect a third of the plants present. Compared with the quadrat technique, LCTA samples overestimated the community contribution of Bouteloua gracilis (H.B.K.) Lag. ex Steud. (blue grama) and underestimated proportions of forbs and sedges. Moreover, LCTA samples are labor intensive and time consuming to collect. Other sampling methods may be needed to detect shifts in species composition towards a less desirable plant community or decreases in biodiversity that may be due to land-use. Thus, it is important for Camp Gilbert $\mathrm{C}$. Grafton (South Unit) to re-evaluate the current standard methodology for monitoring the impacts of military training. Since military installations are located in many different ecosystems, it may be necessary for other installations to likewise examine the usefulness of LCTA techniques in their ecosystems.
\end{abstract}

Key Words: diversity, species richness, grassland vegetation, plant community, prairie, Land Condition Trend Analysis

Research was funded by the North Dakota Army National Guard. The authors wish to thank Drs. Charles Bonham, Gary Clambey, Don Kirby, Jack Norland, and Jack Butler for critical review of the manuscript. We would also like to thank Shawn Dekeyser, Jack Dahl, Dean Cline, Kim Brunelle and Dennis Whitted for the countless hours of data collection for this project.

Manuscript accepted 6 Aug. 2002.

\section{Resumen}

El ejército de E.U.A es responsable de preparar una fuerza de combate bien entrenada y a la vez de mantener la diversidad ecológica y la integridad de los terrenos que el maneja. La habilidad para colectar eficientemente datos que reflejen certeramente la diversidad de la comunidad vegetal y el porcentaje de composición es imperativo para un monitoreo y manejo apropiado de los terrenos del ejercito. Para ayudar a asegurar en forma general que la doble meta del entrenamiento militar y propiedad de la tierra se cumplen en el ejercito, se desarrollo el Programa de Análisis de la Tendencia de la Condición de la Tierra del Ejercito de los Estados Unidos (LCTA). El programa LCTA especifica la metodología estándar del ejercito para la colección, análisis y reporte de datos de los recursos naturales usados para llevara a cabo el inventario y monitoreo de los terrenos. Sin embargo, la técnica de muestreo del LCTA se desarrollo en Colorado y Texas y hay poca información disponible respecto a si estos métodos son apropiados para el inventario y monitoreo de otros ecosistemas de pastizal. Este estudio compara mediciones de riqueza de especies y composición con muestreo de cuadrantes en el área transicional entre las praderas de zacates altos y las de zacates mixtos del Campo Gilbert $C$. Grafton (Unidad Sur) en North Dakota.. La riqueza de especies fue $67 \%$ mayor cuando se uso el muestreo de cuadrantes que cuando se uso la técnica de LCTA, sugiriendo que las muestras del LCTA no detectaron un tercio de las plantas presentes. Comparada con la técnica de cuadrantes, las muestras del LCTA sobreestimaron la contribución que el Bouteloua gracilis (H.B.K.) Lag. ex Steud. ("Blue grama") hace a la comunidad y subestimó proporciones de hierbas y juncos. Más aún, para colectar las muestras del LCTA se requiere de un trabajo intensivo y mucho tiempo. Pueden necesitarse otros métodos de muestreo para detectar desviaciones en la composición de especies hacia una comunidad vegetal menos deseable o disminuciones en la biodiversidad que pueden ser por el uso de la tierra. Así, es importante para el Campo Gilbert C. Grafton (Unidad del Sur) revaluar la metodología estándar actual para monitoreo de los impactos del entrenamiento militar. Ya que las instalaciones militares esta localizadas en muy diferentes ecosistemas, puede ser necesario para otras instalaciones examinar la utilidad de las técnicas del LCTA en sus ecosistemas. 
The U.S. Army is responsible for managing nearly 5.1 million hectares of land on 186 major installations worldwide (U.S. Department of Army 1989). As a result of the limited acreage available and a dramatic increase in the acreage needed for military training and modern weapons testing, these areas have come under intensive use (U.S. Department of Army 1978). The risk of deterioration in land condition comes with increased land use, including accelerated soil erosion and reduced vegetative cover (Barker et al. 1998). Military lands must be carefully managed to preserve the functional and structural integrity of the natural communities, ensure long-term sustainability for future training needs, and to provide a realistic training environment.

In addition to its responsibility for preparing a well-trained combat force, the U.S. Army must maintain the ecological diversity and viability of the lands in its care. Many of these lands are intensively used for a variety of military training activities, but they are also managed for non-military values such as fish and wildlife, recreation, and agriculture. Additionally, the National Environmental Policy Act of 1969 and Army Regulation 200-2 require the Army to minimize any significant short-term and long-term environmental impacts on natural resources (Goran et al. 1983). Furthermore, rare and endangered species, and the habitat necessary to maintain those species on army land, are protected by the Threatened and Endangered Species Act (U.S. Dept. of Interior 1973). Recent legislative trends in environmental impact analysis require quantification of impact estimates. Thus, there is a need to establish cause-effect relationships between Army activities and environmental impacts. Knowledge about these impacts and their short and longterm effects help Army personnel to plan training programs that minimize adverse effects on local ecosystems.

To help ensure that the dual goals of military training and environmental compliance are met on an army-wide basis, the U.S. Army Land Condition-Trend Analysis (LCTA) Program was developed (Diersing et al. 1992). The LCTA program is the Army's standard methodology for the collection, analysis, and reporting of natural resource data used in land inventory and monitoring (Wolff 1990). The objectives of the LCTA program are to promote the principles of sustained yield, land stewardship, and multiple uses of military land resources (Tazik et al. 1992). Specific objectives are to: " 1 ) evaluate the capability of land to meet the multiple-use demands of the U.S. Army on a sustained basis, 2) delineate the biophysical and regulatory constraints to use of the land, 3) monitor changes in land resource condition and evaluate change in terms of current land use, 4) develop and refine land management plans to ensure long-term resource availability, 5) characterize installation natural resources, and 6) implement standards in collection, analysis, and reporting of the data acquired that enable Army-wide data compilation" (Tazik et al. 1992).

The effects of disturbance, such as that caused by military maneuvers, are often quantified by collecting data on vegetation and monitoring for decreases in vegetation abundance (Brady et al. 1995, CEMML 2001). Measuring environmental impact involves inventory of natural resources and monitoring for those resources over time to determine whether ecological changes have occurred. Due to potential threats of exotic plant invasions, the desire to protect native plant diversity, and the need to maintain a realistic military training environment, sampling techniques need to accurately quantify the status and trends of plant diversity on all military installations. Since military installations are scattered throughout the United States, comprising all of the ecoregions and habitat types of North America, it is extremely difficult to develop a "standard" vegetation monitoring technique that can be applied across all military lands, yet this is what has been attempted with the LCTA program. The LCTA program's sampling methods were initially developed in the shortgrass steppe of Colorado and southern mixed prairie of Texas and have subsequently been implemented on military installations across the U.S. (Tazik et al. 1992).

An independent review panel found the LCTA methods to be technologically sound (USALIAC 1989), even though little information is available on whether the LCTA protocol is suitable for vegetation inventory and monitoring in other grassland ecosystems. In this study, we com pared the "standard" protocol currently being used by military installations (LCTA) with a technique that is widely used by plant ecologists and is the standard methodology for vegetation monitoring in mixed grass prairie (Bonham 1989).

Like any other sampling protocol, the LCTA method has its strengths and weaknesses. The LCTA sampling method determines ground cover, surface disturbance, and vertical distribution of the vegetation. Information derived from LCTA samples is also used in evaluating soil erosion status, military concealment cover, wildlife habitat, and botanical composition, and for ground-truthing remotely sensed imagery (Tazik et al. 1992). The major limitation of the LCTA method in the mixed grass prairie is the amount of time needed to gather information from a transect. The second limitation is the low amount of area sampled $\left(60 \mathrm{~cm}^{2}\right)$ per transect, the standard area sampled for all installations on a per transect basis. This may be overcome if a large number of points are sampled, but again, time constraints may not allow monitoring teams to cover large areas. An additional limitation of the LCTA method is that it is not recommended for use in areas where canopy cover is less than $5 \%$ or greater than $35 \%$ (CEMML 2001). The vegetation at Camp Gilbert C. Grafton (South Unit) is quite complex with nearly $100 \%$ canopy cover (Photo 1).

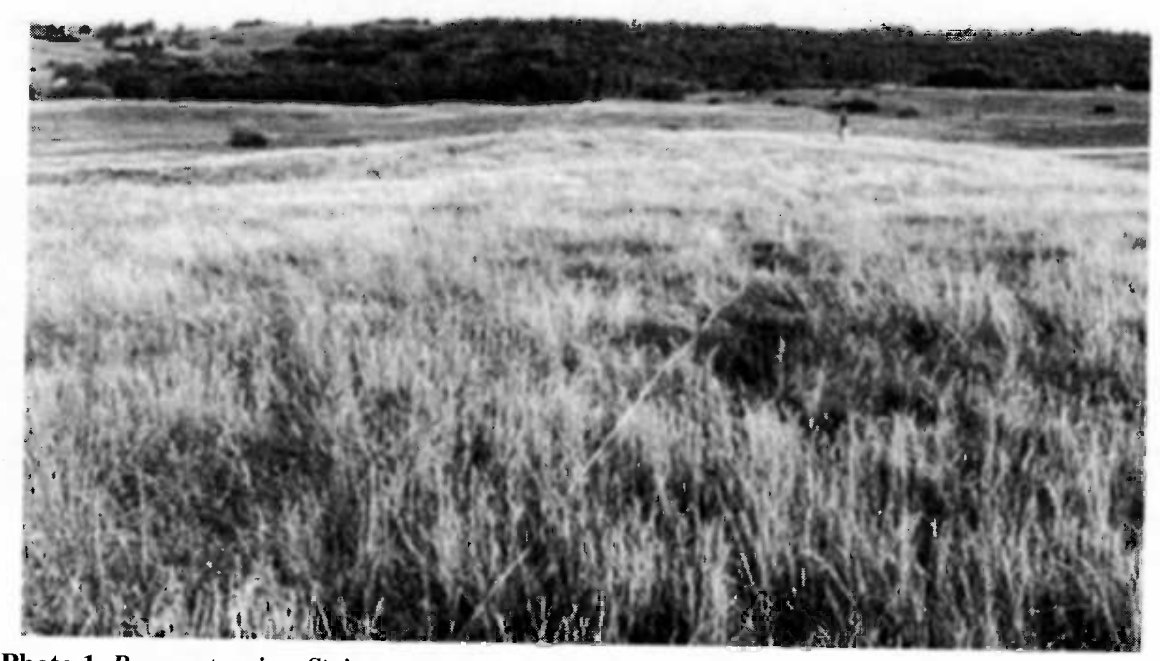

Photo 1. Poa pratensis-Stripa spp. community at Camp Grafton South. 
Alternatives to the LCTA sampling procedures include the use of traditional quadrats, such as $0.10 \mathrm{~m}^{2}$ Daubenmire frames. If the LCTA rod is viewed as a very narrow, vertically oriented quadrat, then these frames or quadrats can be seen as larger, horizontally oriented counterparts with their own strengths and weaknesses. The larger quadrat allows a greater area to be sampled in a short period of time and greater flexibility in size of quadrats used. However, quadrat sampling does not measure military concealment cover nor vertical distribution of the vegetation.

Observed differences between data obtained using the LCTA protocol and quadrats in the field led to this study, which compared the 2 methods to determine which technique best captures baseline vegetation conditions at Camp Grafton South, an area developed in 1983 to support the training needs of the North Dakota Army National Guard. This training site is also used by the North Dakota Air National Guard; Army National Guard units from other states; the U.S. Army Reserve; various Reserve Officer Training Corps units; and active component units of the U.S. Army, Navy, and Air Force. The North Dakota Army National Guard recently introduced tracked vehicles to some of its land units ("mechanized units"). These vehicles have the potential to negatively affect the natural environment, posing new management challenges to the training site (Barker et al. 1998). Milchunas et al. (2000) concluded that long-term disturbance from mechanized military maneuvers can cause plant mortality and indirectly affect plant communities through soil compaction and by altering competitive relationships within the plant community. With the addition of tracked vehicles, vegetation and soil properties need to be monitored on these installations to ensure that no irreparable harm will occur to the sites' natural resources.

The LCTA program was used as part of a larger effort that also included quadrat sampling methods to describe the native vegetation of the transitional grasslands of Camp Grafton South. Initial observations indicated that quadrats consistently detected more species than did sampling using the LCTA techniques, that LCTA sampling failed to detect a large proportion of the forbs and sedges present, and that LCTA samples resulted in higher percent composition estimates of dominant grasses than did quadrat samples (K. Sedivec, personal communication). The objective of this study was to compare the LCTA monitoring technique with quadrat sampling to

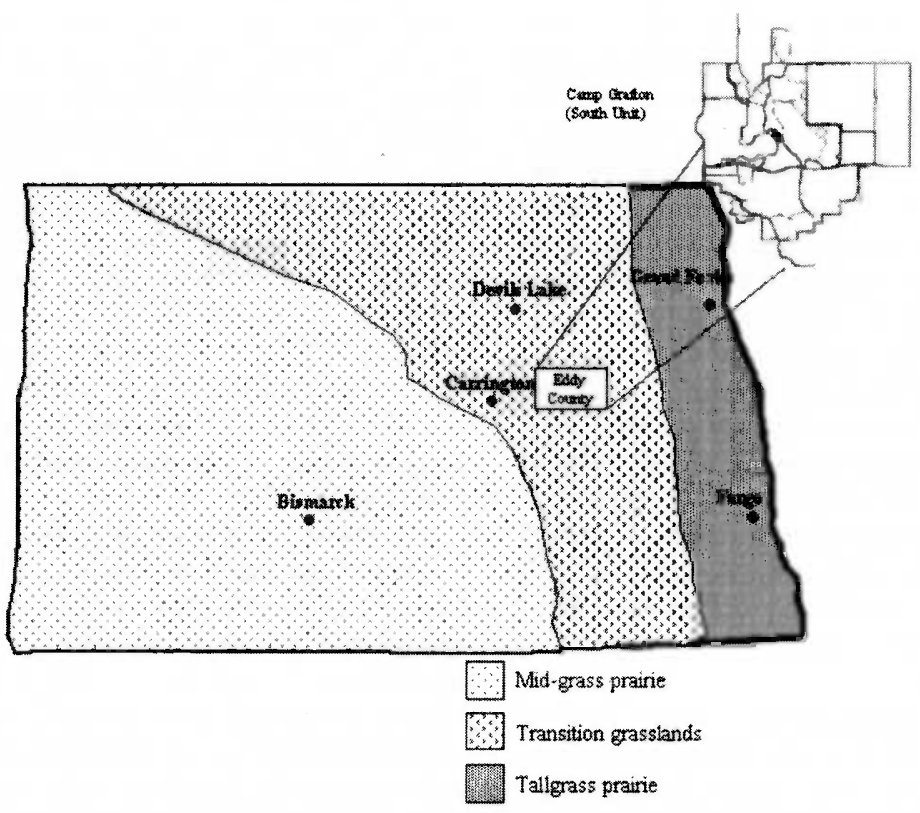

Fig. 1. Location of Eddy County and Camp Gilbert C. Grafton (South Unit) within North Dakota and the major vegetation zones across the state (modified from Küchler 1964 and Barker and Whitman 1988 and 1989). describe the species richness and percent composition of vegetation on a military installation in east-central North Dakota in an area known as the transitional grasslands.

\section{Methods}

\section{Study Area}

Camp Gilbert C. Grafton (South Unit) is located approximately $56 \mathrm{~km}$ southwest of Devils Lake, North Dakota, and has an area of approximately 3,470 ha (Barker et al. 1998) (Fig. 1). This study was conducted in the southeast corner of Eddy County, between $47^{\circ} 40^{\prime}$ to $47^{\circ} 45^{\prime} \mathrm{N}$ Lat and $98^{\circ} 35^{\prime}$ to $98^{\circ} 43^{\prime} \mathrm{W}$ Long (Fig. 1), in the Drift Prairie physiographic zone of the Transitional Grasslands prairie region (Barker and Whitman 1989). Vegetation in these transitional grasslands is a combination of mixed-grass and tallgrass prairie plants (Whitman and Wali 1975, Barker and Whitman 1989). Küchler (1964) classified the potential natural vegetation of this northern transition grass prairie as a moderately dense, short to medium tall Wheatgrass-Bluestem-Needlegrass (Agropyron-Andropogon-Stipa) association. The transitional grassland type lies between the Bluestem prairie to the east and the drier Wheatgrass-Needlegrass association to the west. The study area is administered by the North Dakota Army National Guard and has been grazed by cattle for many years.

The vegetative plant communities within the study area were designated high-, mid- and low-prairie based on topography and drainage (Fig. 2). The high-prairie

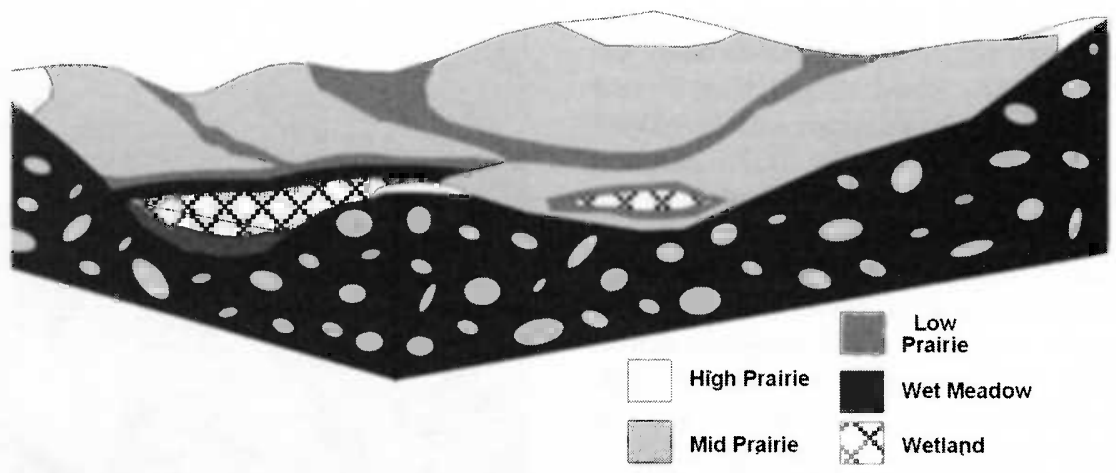

Fig. 2. Hypothetical block diagram of Camp Grafton South, modified from Dix and Smeins (1967). 
(upland) was classified as an area that includes steep shoulder slopes and tops of knolls that lose most of their moisture to runoff. The mid-prairie (midland) was classified as areas that include back slopes with moderate infiltration. The low-prairie (lowland) was classified as an area that occupies the footslope and toeslope positions on the landscape. A visible zonation of plant communities occurred across these 3 topographic areas.

Average annual precipitation (29-year average) at the McHenry weather station was $47.3 \mathrm{~cm}$ per year (NOAA 1995-1997). Annual precipitation was $63.2 \mathrm{~cm}, 47.5$ $\mathrm{cm}$, and $29.4 \mathrm{~cm}$ for 1995,1996 , and 1997, respectively. The 29-year average precipitation was $8.7 \mathrm{~cm}$ in June, $6.7 \mathrm{~cm}$ in July, and $6.9 \mathrm{~cm}$ in August. Precipitation was below the 29-year average for June and above the average for July for all 3. years. Precipitation was below the 29-year average for August, totalling $5.5 \mathrm{~cm}, 3.1$ $\mathrm{cm}$, and $3.5 \mathrm{~cm}$ for 1995,1996 , and 1997 , respectively.

\section{Sampling Methods}

The Land Condition-Trend Analysis (LCTA) vegetation surveys consist of 3 main components: line point transect aerial cover surveys, line point transect ground cover surveys, and belt transect surveys (Tazik et al. 1992). The line transect aerial cover survey characterizes canopy cover, species composition and distribution (Photo 2). The line transect ground cover survey characterizes basal cover, species composition, distribution, and surface disturbance. Data from the line transect surveys were recorded using a modified point intercept method (Levy and Madden 1933, Goodall 1952, 1953 , Mueller-Dombois and Ellenberg 1974). Forty-five, $100 \mathrm{~m}$ transects were randomly located on native prairie at Camp Grafton South during the springs of 1995-1997 (15 per year) using the GIS software program IDRISI (Fig. 3). According to Tazik et al. (1992), the number of plots established at any given installation should be based on the size and variability of the area. As a rule of thumb, there should be approximately 1 plot per 200 ha. The CGS comprises 3,470 ha, suggesting that 18 transects would be sufficient to monitor the natural resources at this installation. This study evaluated 45 transects, 2.5 times the recommended number (Tazik et al. 1992). Transects were proportionately allocated, using total hectares of vegetation type within the upland $(n=18)$, midland $(n=17)$ and lowland $(n=10)$ communities, and were located in the field

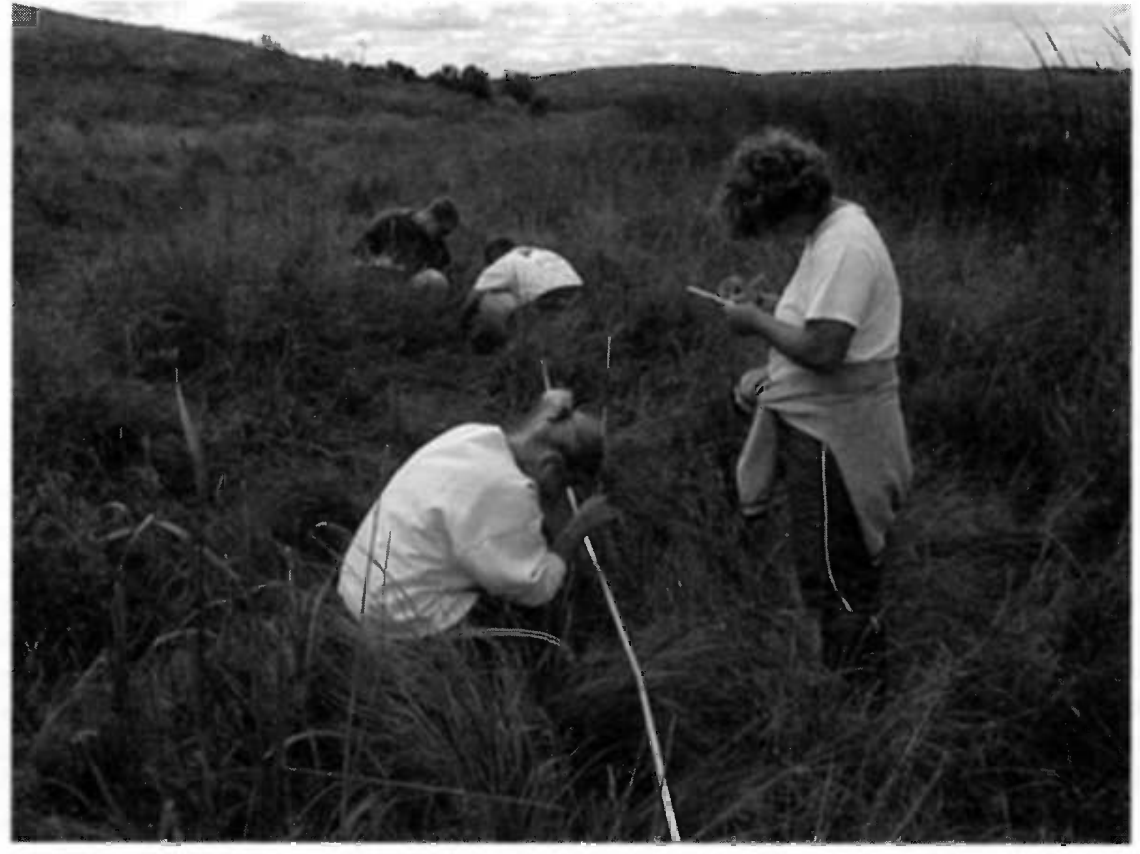

Photo 2. Sampling vegetation using LCTA methodology. (Note vertical rod). with a hand-held global positioning system (GPS) receiver.

Using the Army's LCTA Program methodology, 100 points were sampled along each line transect, beginning at the
$0.5 \mathrm{~m}$ point and continuing at $1 \mathrm{~m}$ intervals along the measuring tape (Tazik et al. 1992). A $1 \mathrm{~m}$ tall, $6 \mathrm{~mm}$ diameter measuring rod was placed perpendicular to the ground at each point. The pre-

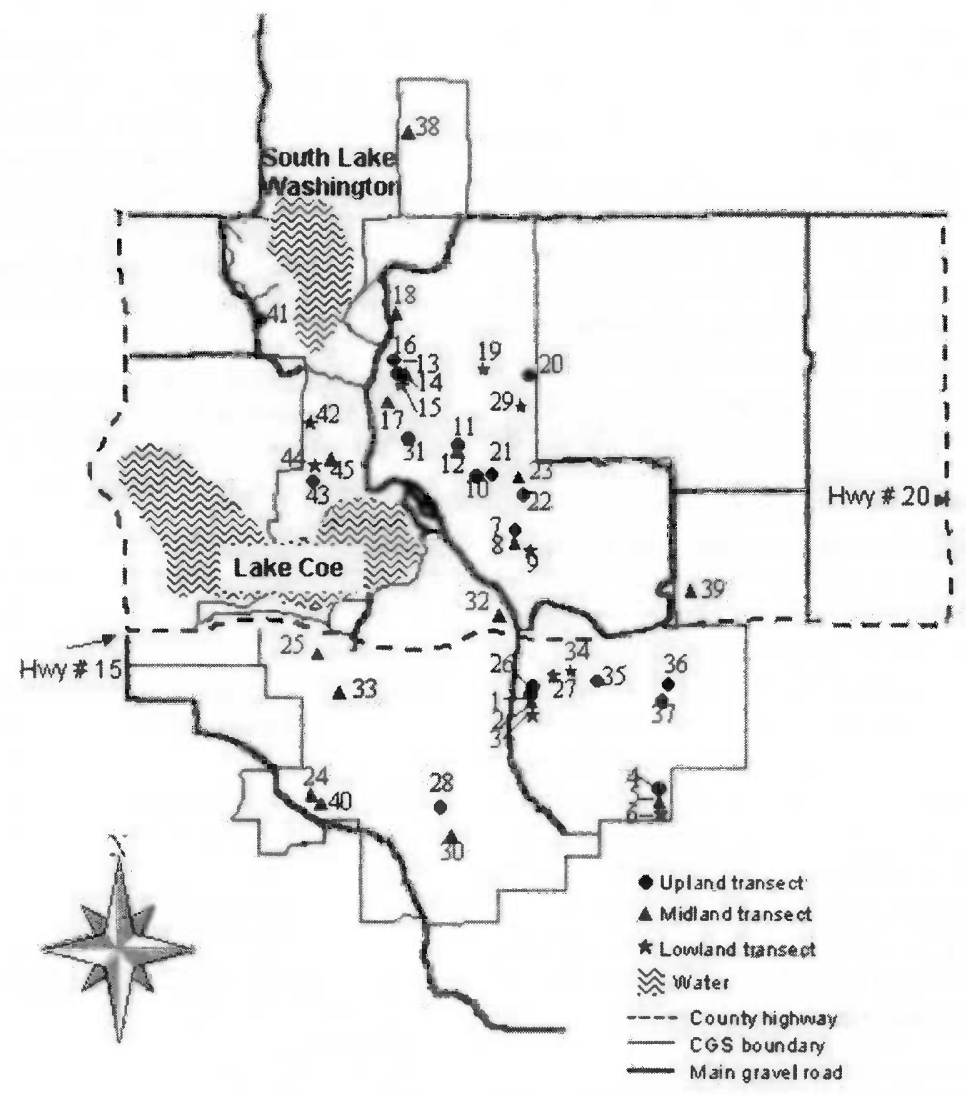

Fig. 3. Location of $\mathbf{4 5}$ grassland transects at Camp Grafton South. 
sence/absence of forb and graminoid species were determined by recording vegetation contacts ("hits") on the measuring rod. If a species touched the rod at more than 1 place, only 1 "hit" was recorded for that point, indicating presence of that species.

Quadrats were also sampled to detect the presence/absence of graminoid and forb species. Quadrats were sampled every $5 \mathrm{~m}$ along the $100 \mathrm{~m}$ transects using a 0.25 $\mathrm{m}^{2}$ frame for forb frequency and, within the $0.25 \mathrm{~m}^{2}$ frame, a $0.1 \mathrm{~m}^{2}$ frame to determine frequency of graminoid species, after Biondini et al. (1989), Stohlgren et al. (1998) and Daubenmire (1959). The larger $0.25 \mathrm{~m}^{2}$ frame was used to determine presence/absence for forbs due to the inherent spatial patchiness of forb species (Biondini et al. 1989). The LCTA and quadrat samples were taken at the same locations and transects at the same time. Plant species nomenclature followed the Great Plains Flora (Great Plains Flora Association 1986).

\section{Data Analysis}

We calculated species richness for each transect to determine whether the 2 sampling techniques equally measured plant community diversity. Species richness was calculated as the total number of species observed along each transect. Additionally, the percent composition of selected species was calculated as an index of community dominance. Carex spp., Stipa spp., Artemisia frigida Willd. (fringed sagebrush), Helianthus rigidus (Cass.) Desf. (stiff sunflower) and Bouteloua gracilis (H.B.K.) Lag. ex Steud. (blue grama) were selected as species of interest because they were representative of the communities in the study area, present in most transects, and detected using both sampling techniques.

Presence/absence (frequency) data collected using LCTA techniques can be used to characterize plant community composition and serve as baseline data to detect changes in vegetation over time (Price et al. 1995). However, because frequency data are highly dependent on the size of the area sampled (Bonham 1989), we converted the presence/absence measures to percent composition. We calculated percent composition as the proportion that each species of interest contributed to the local community (Skinner 1995) by dividing the number of "hits" (or number of quadrats in which the species was present) along each transect by the sum of all "hits" for all species encountered:

Percent composition $=$ no. of hits of species A $\quad X 100$ total no. of hits for all species

Table 1. Summary statistics. "LCTAspp" is species richness as measured by the LCTA Method and "quadratspp" is species richness as measured using quadrats for the upland, midland and lowland communities at Camp Grafton South.

\begin{tabular}{llllccc}
\hline \hline $\begin{array}{l}\text { Topographic } \\
\text { Position }\end{array}$ & Variable & $\mathrm{N}$ & Mean & $\begin{array}{c}\text { Std } \\
\text {. Deviation }\end{array}$ & Minimum & Maximum \\
\hline Upland & LCTAspp & 18 & 12.83 & 4.74 & 7 & 22 \\
& quadratspp & 18 & 20.11 & 8.68 & 9 & 38 \\
\multirow{3}{*}{ Midland } & LCTAspp & 17 & 12.71 & 5.65 & 6 & 26 \\
& quadratspp & 17 & 22.06 & 10.76 & 9 & 48 \\
Lowland & LCTAspp & 10 & 11 & 6.39 & 5 & 23 \\
& quadratspp & 10 & 16.8 & 8.05 & 8 & 30 \\
& LCTAspp & 45 & 12.38 & 5.41 & 5 & 26 \\
& quadratspp & 45 & 20.11 & 9.4 & 8 & 48 \\
\hline
\end{tabular}

Wilcoxon's signed-rank test for 2 related samples was used to test for significant differences in the distributions of the data collected with the 2 sampling protocols. Wilcoxon's test was run first on all transects and then individually on lowland, midland, and upland transects. Wilcoxon's signed-rank test was conducted on the percent composition in the same manner as for species richness.

\section{Results}

Species richness. The quadrat sampling resulted in consistently higher values for species richness than the Land ConditionTrend Analysis (LCTA) Program's sampling method (Table 1). This was true for all 3 topographic areas (upland, midland, and lowland prairie). Sampling with larger quadrats detected about $67 \%$ more species on average than did the LCTA method (Table 1). The difference between species richness as measured by the 2 methods

Table 2. Results of Wilcoxon signed-ranks test. "LCTAspp" is species richness as measured by the LCTA method and "quadratspp" is species richness as measured using quadrats for the upland, midland, lowland and all grassland communities at Camp Grafton South.

\begin{tabular}{|c|c|c|c|c|c|c|}
\hline $\begin{array}{l}\text { Topographic } \\
\text { Position }\end{array}$ & Ranks & $\mathrm{N}$ & $\begin{array}{l}\text { Mean } \\
\text { Rank }\end{array}$ & $\begin{array}{c}\text { Sum of } \\
\text { Ranks }\end{array}$ & $\mathrm{Z}$ & $\begin{array}{c}\text { Asymp. Sig. } \\
\text { (2-tailed) }\end{array}$ \\
\hline Upland & $\begin{array}{l}\text { Negative ranks } \\
\text { Positive ranks } \\
\text { Ties }^{3}\end{array}$ & $\begin{array}{c}1 \\
15 \\
2\end{array}$ & $\begin{array}{l}1.50 \\
8.97\end{array}$ & $\begin{array}{r}1.50 \\
134.50\end{array}$ & $-3.446^{4}$ & $.001 * *$ \\
\hline Midland & $\begin{array}{l}\text { Negative ranks }{ }^{1} \\
\text { Positive ranks }^{2} \\
\text { Ties }^{3}\end{array}$ & $\begin{array}{c}0 \\
16 \\
1\end{array}$ & 8.50 & 136.00 & $-3.519^{4}$ & $.000 * *$ \\
\hline Lowland & $\begin{array}{l}\text { Negative ranks }{ }^{1} \\
\text { Positive ranks }^{2} \\
\text { Ties }^{3}\end{array}$ & $\begin{array}{c}0 \\
10 \\
0\end{array}$ & $\overline{5.50}$ & $\overline{--}$ & $-2.819^{4}$ & $.005^{* *}$ \\
\hline All & $\begin{array}{l}\text { Negative ranks }{ }^{1} \\
\text { Positive ranks } \\
\text { Ties }^{3}\end{array}$ & $\begin{array}{c}1 \\
41 \\
3\end{array}$ & $\begin{array}{r}2.00 \\
21.98\end{array}$ & $\begin{array}{r}2.00 \\
901.00\end{array}$ & $-5.625^{4}$ & $.000 * *$ \\
\hline
\end{tabular}

* Significant at 0.05 level

**Significant at 0.01 level

'quadratspp < LCTAspp

2 quadratspp $>$ LCTAspp

quadratspp = LCTAspp

${ }^{4}$ based on negative ranks 
Table 3. Results of Wilcoxon signed-ranks test. "LCTACarex" is percent composition of Carex spp. as measured by the LCTA method and "quadrat Carex" is percent composition of Carex spp. as measured using quadrats for the upland, midland, lowland and all grassland communities at Camp Grafton South.

\begin{tabular}{|c|c|c|c|c|c|c|}
\hline $\begin{array}{l}\text { Topographic } \\
\text { Position }\end{array}$ & Ranks & $\mathrm{N}$ & $\begin{array}{l}\text { Mean } \\
\text { Rank }\end{array}$ & $\begin{array}{c}\text { Sum of } \\
\text { Ranks }\end{array}$ & Z & $\begin{array}{c}\text { Asymp. Sig. } \\
\text { (2-tailed) }\end{array}$ \\
\hline$\overline{\text { Upland }}$ & $\begin{array}{l}\text { Negative ranks }{ }^{1} \\
\text { Positive ranks }^{2} \\
\text { Ties }^{3}\end{array}$ & $\begin{array}{c}0 \\
18 \\
0\end{array}$ & $\begin{array}{l}0.00 \\
9.50\end{array}$ & $\begin{array}{r}0.00 \\
171.00\end{array}$ & $-3.724^{4}$ & $.000^{* *}$ \\
\hline Midland & $\begin{array}{l}\text { Negative ranks }{ }^{1} \\
\text { Positive ranks }^{2} \\
\text { Ties }^{3}\end{array}$ & $\begin{array}{c}0 \\
13 \\
4\end{array}$ & $\begin{array}{l}0.00 \\
7.00\end{array}$ & $\begin{array}{r}0.00 \\
91.00\end{array}$ & $-3.180^{4}$ & $.001 * *$ \\
\hline Lowland & $\begin{array}{l}\text { Negative ranks }{ }^{1} \\
\text { Positive ranks }^{2} \\
\text { Ties }^{3}\end{array}$ & $\begin{array}{l}0 \\
8 \\
2\end{array}$ & $\begin{array}{l}0.00 \\
4.50\end{array}$ & $\begin{array}{r}0.00 \\
36.00\end{array}$ & $-2.521^{4}$ & $.012 *$ \\
\hline All & $\begin{array}{l}\text { Negative ranks }{ }^{1} \\
\text { Positive ranks }^{2} \\
\text { Ties }^{3}\end{array}$ & $\begin{array}{c}0 \\
39 \\
6\end{array}$ & $\begin{array}{r}0.00 \\
20.00\end{array}$ & $\begin{array}{r}0.00 \\
780.00\end{array}$ & $-5.442^{4}$ & $.000 * *$ \\
\hline
\end{tabular}

*Significant at 0.05 level

**Significant at 0.01 level

Table 4. Results of Wilcoxon signed-ranks test. "LCTAStipa" is percent composition of Stipa spp. as measured by the LCTA method and "quadratStipa" is percent composition of Stipa spp. as measured using quadrats for the upland, midland, lowland and all grassland communities at Camp Grafton South.

\begin{tabular}{llccccc}
\hline \hline $\begin{array}{l}\text { Topographic } \\
\text { Position }\end{array}$ & Ranks & $\mathrm{N}$ & $\begin{array}{c}\text { Mean } \\
\text { Rank }\end{array}$ & $\begin{array}{c}\text { Sum of } \\
\text { Ranks }\end{array}$ & $\mathrm{Z}$ & $\begin{array}{c}\text { Asymp. Sig. } \\
\text { (2-tailed) }\end{array}$ \\
\hline Upland & Negative ranks $^{1}$ & 16 & 9.94 & 159.00 & $-3.201^{4}$ & $.001^{* *}$ \\
& Positive ranks $^{2}$ & 2 & 6.00 & 12.00 & & \\
& Ties $^{3}$ & 0 & & & & \\
Midland & Negative ranks $^{1}$ & 14 & 9.50 & 133.00 & $-2.675^{4}$ & $.007^{* *}$ \\
& Positive ranks $^{2}$ & 3 & 6.67 & 20.00 & & \\
& Ties $^{3}$ & 0 & & & & \\
Lowland & Negative ranks $^{1}$ & 3 & 4.00 & 12.00 & $-1.244^{5}$ & .214 \\
& Positive ranks $^{2}$ & 6 & 5.50 & 33.00 & & \\
All & Ties $^{3}$ & 1 & & & & \\
& Negative ranks $^{1}$ & 33 & 24.64 & 813.00 & $-3.711^{4}$ & $.000^{* *}$ \\
& Positive ranks $^{2}$ & 11 & 16.09 & 177.00 & & \\
\hline
\end{tabular}

*Significant at 0.05 level

**Significant at 0.01 leve

quadratspp $<$ LCTAspp

${ }^{2}$ quadratspp $>$ LCTAspp

3 quadratspp $=$ LCTAspp

4 based on negative ranks

5 based on negative ranks

Table 5. Results of Wilcoxon signed-ranks test. "LCTAARFR" is percent composition of Artemisia frigida (fringed sagebrush) as measured by the LCTA method and "quadratARFR" is percent composition of fringed sagebrush as measured using quadrats for the upland, midland, lowland and all grassland communities at Camp Grafton South.

\begin{tabular}{|c|c|c|c|c|c|c|}
\hline $\begin{array}{l}\text { Topographic } \\
\text { Position }\end{array}$ & Ranks & $\mathrm{N}$ & $\begin{array}{l}\text { Mean } \\
\text { Rank }\end{array}$ & $\begin{array}{c}\text { Sum of } \\
\text { Ranks }\end{array}$ & $\mathrm{Z}$ & $\begin{array}{c}\text { Asymp. Sig. } \\
\text { (2-tailed) }\end{array}$ \\
\hline Upland & $\begin{array}{l}\text { Negative ranks } \\
\text { Positive ranks } \\
\text { Ties }^{3}\end{array}$ & $\begin{array}{c}0 \\
7 \\
11\end{array}$ & $\begin{array}{l}0.00 \\
4.00\end{array}$ & $\begin{array}{r}0.00 \\
28.00\end{array}$ & $-2.366^{4}$ & $.000^{* *}$ \\
\hline Midland & $\begin{array}{l}\text { Negative ranks }{ }^{1} \\
\text { Positive ranks } \\
\text { Ties }^{3}\end{array}$ & $\begin{array}{c}0 \\
6 \\
11\end{array}$ & $\begin{array}{l}0.00 \\
3.50\end{array}$ & $\begin{array}{r}0.00 \\
21.00\end{array}$ & $-2.201^{4}$ & $.028 *$ \\
\hline Lowland & $\begin{array}{l}\text { Negative ranks }{ }^{1} \\
\text { Positive ranks }{ }^{2} \\
\text { Ties }^{3}\end{array}$ & $\begin{array}{l}0 \\
3 \\
7\end{array}$ & $\begin{array}{l}0.00 \\
2.00\end{array}$ & $\begin{array}{l}0.00 \\
6.00\end{array}$ & $-1.604^{4}$ & .109 \\
\hline All & $\begin{array}{l}\text { Negative ranks } \\
\text { Positive ranks }^{2} \\
\text { Ties }^{3}\end{array}$ & $\begin{array}{r}0 \\
16 \\
29\end{array}$ & $\begin{array}{l}0.00 \\
8.50\end{array}$ & $\begin{array}{r}0.00 \\
136.00\end{array}$ & $-3.516^{4}$ & $.000 * *$ \\
\hline $\begin{array}{l}\text { Significant at } 0 \\
{ }^{* *} \text { Significant a } \\
{ }_{1} \text { quadratspp }<1 \\
{ }_{2} \text { quadratspp }>1 \\
{ }_{3} \text { quadratspp = } \\
{ }_{\text {b }} \text { based on nega }\end{array}$ & $\begin{array}{l}.05 \text { level } \\
\text { t } 0.01 \text { level } \\
\text { LCTAspp } \\
\text { LCTAspp } \\
\text { LCTAspp } \\
\text { tive ranks }\end{array}$ & & & & & \\
\hline
\end{tabular}

composition of blue grama were greater when measured with the quadrats in midland transects (Table 7). No significant differences between sampling methods were found for Stipa spp., fringed sagebrush, stiff sunflower or blue grama on lowland transects.

The raw data revealed the strengths and weaknesses of both sampling methods. The LCTA method detected shrubs more often than did quadrats, but LCTA methods failed to detect a sizable proportion of the forbs present. For example, in upland transect 37 there were 4 species of forbs detected using LCTA methods and an additional 14 forb species were found using quadrats (Table 8). Individually, these forbs had percent compositions of less than $10 \%$ but their combined contribution to the community was $55 \%$. Similarly, only about half as many forbs were detected by LCTA as by quadrats in transects 24 and 29 (midland and lowland transects, respectively). Percent composition of dominant grasses also differed substantially between sampling methods. The LCTA method resulted in percent compositions for Poa pratensis that were several times higher than the values calculated from data gathered using quadrats (Table 8).

\section{Discussion}

Rangeland conservation is increasingly concerned with maintaining native plant diversity, detecting exotic species, and monitoring rare species (Mack 1981, U.S. GAO 1991, National Research Council 1994, Joern and Keeler 1995, Randall 1966, Stohlgren et al 1998). Because rangeland inventory and monitoring needs have increased in the face of decreased funding to monitor rangelands (National Research Council 1994), sampling techniques must be more cost-efficient and information rich than ever before. Military training lands are no exception. As management challenges on military installations become more complex, the sampling techniques used to monitor vegetation must provide relevant information linking land use with environmental change (Brady et al. 1995, Stohlgren et al. 1998). Based on our results, the Land ConditionTrend Analysis (LCTA) Program methodology did not adequately detect rare or subdominant species, a serious limitation to monitoring efforts at Camp Grafton South.

Species richness. Like the work of Stohlgren and coworkers (1998) in the northern mixed prairie, we found that the 
Table 6. Results of Wilcoxon signed-ranks test. "LCTAHERI" is percent composition of Helianthus rigida (rigid sunflower) as measured by the LCTA method and "quadratHERI" is percent composition of rigid sunflower as measured using quadrats for the upland, midland, lowland and all grassland communities at Camp Grafton South.

\begin{tabular}{|c|c|c|c|c|c|c|}
\hline $\begin{array}{l}\text { Topographic } \\
\text { Position }\end{array}$ & Ranks & $\mathrm{N}$ & $\begin{array}{l}\text { Mean } \\
\text { Rank }\end{array}$ & $\begin{array}{l}\text { Sum of } \\
\text { Ranks }\end{array}$ & Z & $\begin{array}{l}\text { Asymp. Sig. } \\
\text { (2-tailed) }\end{array}$ \\
\hline Upland & $\begin{array}{l}\text { Negative ranks } \\
\text { Positive ranks }{ }^{2} \\
\text { Ties }^{3}\end{array}$ & $\begin{array}{c}0 \\
7 \\
11\end{array}$ & $\begin{array}{l}0.00 \\
4.00\end{array}$ & $\begin{array}{r}0.00 \\
28.00\end{array}$ & $-2.366^{4}$ & $.018^{*}$ \\
\hline Midland & $\begin{array}{l}\text { Negative ranks }{ }^{1} \\
\text { Positive ranks }{ }^{2} \\
\text { Ties }^{3}\end{array}$ & $\begin{array}{c}1 \\
6 \\
10\end{array}$ & $\begin{array}{l}1.00 \\
4.50\end{array}$ & $\begin{array}{r}1.00 \\
27.00\end{array}$ & $-2.197^{4}$ & $.028 *$ \\
\hline Lowland & $\begin{array}{l}\text { Negative ranks }{ }^{1} \\
\text { Positive ranks }{ }^{2} \\
\text { Ties }^{3}\end{array}$ & $\begin{array}{l}0 \\
1 \\
9\end{array}$ & $\begin{array}{l}0.00 \\
1.00\end{array}$ & $\begin{array}{l}0.00 \\
1.00\end{array}$ & $-1.000^{4}$ & .317 \\
\hline All & $\begin{array}{l}\text { Negative ranks }{ }^{1} \\
\text { Positive ranks }^{2} \\
\text { Ties }^{3}\end{array}$ & $\begin{array}{c}1 \\
14 \\
30\end{array}$ & $\begin{array}{l}2.00 \\
8.43\end{array}$ & $\begin{array}{r}2.00 \\
118.00\end{array}$ & $-3.294^{4}$ & $.001^{* *}$ \\
\hline
\end{tabular}

*Significant at 0.05 level

$* *$ Significant at 0.01 level

${ }^{* * \text { Significant at } 0.01 \text { leve }}$

2 quadratspp $>$ LCTAspp

quadratspp $=$ LCTAspp

based on negative ranks

2 sampling techniques differed in the number of species detected. Sampling with LCTA did not capture as much of the plant diversity of the study area as quadrat sampling. This may not be a serious problem when species richness is low and there are few species to sample, but the vegetation at Camp Grafton South is quite complex, with nearly $100 \%$ canopy cover and approximately 600 species present (Dekeyser 1995) (Photo 3). Our results may have been expected, as the LCTA protocol is not recommended for use in areas where canopy cover is less than $5 \%$ or greater than 35\% (CEMML 2001). Unlike the communities in Texas and Colorado where the LCTA methods were developed, the dense cover at this installation clearly falls outside of this recommended range, indicating that other methods should be investigated for use at this installation.

There are 2 main reasons that the LCTA point-intercept method did not capture the full plant diversity present at Camp Grafton South. First, the vegetation in the study area produces a thick layer of litter that is not disturbed when sampling using a rod (but which is removed when sampling with quadrats). Thus, plants of small stature may have been obscured by the litter and remained undetected when sampling with the LCTA protocol. Second, the LCTA Program sampling technique uses a $6 \mathrm{~mm}$ diameter rod to intercept vegetation at 100 points along each transect. This results in a very small area covered (60 $\mathrm{cm} 2$ ) compared with quadrats that each cover 0.1 to $0.25 \mathrm{~m}^{2}$ of area. However, the LCTA sampling technique also records "hits" by species that are adjacent to the rod and not actually growing in the area of the diversity of the plant community at Camp Grafton South.

*Significant at 0.05 level

**Significant at 0.01 level

${ }_{2}^{1}$ quadratspp < LCTAspp

${ }_{3}^{2}$ quadratspp $>$ LCTAspp

quadratspp $=$ LCTAspp

based on negative ranks

5 based on negative ranks
Percent composition. The LCTA technique underestimated the percent composition of forbs and sedges, compared with quadrat sampling, due in part to reduced detection of the presence of these subdominant species. Price and coworkers (1995) concluded from LCTA techniques at Fort Hood, Texas, that sampling intensity may be sufficient for major species but insufficient for minor species. Our findings at Camp Grafton South were very similar to those found at Fort Hood, indicating that similar problems may arise even in the more arid areas where the LCTA Program was developed. Price and coworkers (1995) also concluded that minor species often are not normally distributed, making it difficult to detect the minor species using the LCTA method unless a very large number of points were sampled along each transect (CEMML 2001). However, this is not a feasible remedy because of the time it would involve. The LCTA technique took 2 to 2.5 hours per site versus 1 hour when sampling with quadrats.

Detecting and monitoring locally rare species or subdominant species in rangeland is important because less common species are a major component of plant diversity. These subdominant species are the same species that will likely be lost if there is a shift in species composition due to disturbance or invasion of less desirable species (Stohlgren et al. 1998). Camp Gilbert C. Grafton (South Unit) currently has 4 species that are considered threatened in North Dakota, Carex pseudo-cype-

\begin{tabular}{|c|c|c|c|c|c|c|}
\hline $\begin{array}{l}\text { Topographic } \\
\text { Position }\end{array}$ & Ranks & $\mathrm{N}$ & $\begin{array}{l}\text { Mean } \\
\text { Rank }\end{array}$ & $\begin{array}{l}\text { Sum of } \\
\text { Ranks }\end{array}$ & $\mathrm{Z}$ & $\begin{array}{c}\text { Asymp. Sig. } \\
\text { (2-tailed) }\end{array}$ \\
\hline Upland & $\begin{array}{l}\text { Negative ranks } \\
\text { Positive ranks } \\
\text { Ties }^{3}\end{array}$ & $\begin{array}{c}10 \\
7 \\
1\end{array}$ & $\begin{array}{r}11.50 \\
5.43\end{array}$ & $\begin{array}{r}115.00 \\
38.00\end{array}$ & $-1.823^{4}$ & .068 \\
\hline Midland & $\begin{array}{l}\text { Negative ranks }{ }^{1} \\
\text { Positive ranks }{ }^{2} \\
\text { Ties }^{3}\end{array}$ & $\begin{array}{c}1 \\
11 \\
5\end{array}$ & $\begin{array}{r}12.00 \\
6.00\end{array}$ & $\begin{array}{l}12.00 \\
66.00\end{array}$ & $-2.118^{5}$ & $.034^{*}$ \\
\hline Lowland & $\begin{array}{l}\text { Negative ranks }{ }^{1} \\
\text { Positive ranks }{ }^{2} \\
\text { Ties }^{3}\end{array}$ & $\begin{array}{l}3 \\
4 \\
3\end{array}$ & $\begin{array}{l}2.33 \\
5.25\end{array}$ & $\begin{array}{r}7.00 \\
21.00\end{array}$ & $-1.183^{5}$ & .237 \\
\hline All & $\begin{array}{l}\text { Negative ranks }{ }^{1} \\
\text { Positive ranks }{ }^{2} \\
\text { Ties }^{3}\end{array}$ & 14 & 22.93 & 321.00 & $-0.189^{5}$ & .850 \\
\hline
\end{tabular}


rus L. (cyperus-like sedge), Carex buxbaumii Wahl., Cyprideum calceolus L.(large yellow lady's-slipper orchid), and Cypripedium candidum Muhl. Ex Willd. (small white lady's-slipper orchid) (North Dakota Outdoors 1986). It is imperative that these threatened, rare or subdominant species be monitored through a welldesigned vegetation sampling protocol because of their importance to the diversity of the plant community and their contribution to the overall health and structural integrity of Camp Grafton South. Although we do not know the "true" percent composition of species of this landscape, our data suggest that sampling with quadrats is better than LCTA sampling for measuring species compositions at this installation. It may be necessary to conduct studies evaluating various quadrat sizes and numbers of plots to determine the most time-efficient and information rich method. One such method is a species-area curve, which uses nested quadrats to find the relationship between number of species present and area sampled. This method is used to find the minimal area and number of quadrats needed to adequately sample vegetation. Since military installations are located in many different ecosystems, it may be necessary for other installations to develop their own species-area curve and likewise evaluate the usefulness of the LCTA methodology in their ecosystems. Further research is needed to evaluate other sampling techniques and determine the method that most accurately and efficiently captures the data necessary to successfully monitor the training lands of the North Dakota Army National Guard.

\section{Conclusion}

The U.S. Army Land Condition-Trend Analysis (LCTA) Program's inventory and monitoring methods may be suitable for the semi-arid ecosystems where they were developed, but fail to accurately portray the community diversity and species composition of North Dakota's complex transitional prairie. The LCTA sampling protocol is currently being used on Army installations worldwide; however, our results suggest that the "one-size-fits-all" approach of using the same sampling methods for all Army installations needs to be re-evaluated. Although there are several advantages to using the LCTA technique, such as measuring military concealment and vertical distribution of the vegetation, military land managers may not be detect a
Table 8. Representative data for upland, midland, and lowland transects at Camp Grafton South. Transect 37 represents a community located in the high prairie (upland), transect 24 is located in the mid prairie (midland), and transect 29 is located in the low prairie (lowland) portion of the study area.

\begin{tabular}{|c|c|c|c|c|}
\hline Transect & Species & Plant Group ${ }^{1}$ & $\begin{array}{l}\text { LCTA percent } \\
\text { composition }\end{array}$ & $\begin{array}{l}\text { Quadrat percent } \\
\text { composition }\end{array}$ \\
\hline \multicolumn{5}{|l|}{$\overline{37}$} \\
\hline & Bromus inermis & G & 1.55 & 0.962 \\
\hline & Calamovilfa longifolia & G & 1.55 & 1.92 \\
\hline & Poa pratensis & G & 76.7 & 19.2 \\
\hline & Stipa viridula & G & 3.10 & 8.65 \\
\hline & Ambrosia psilostachya & $\mathrm{F}$ & 0.775 & 3.85 \\
\hline & Galium boreale & $\mathrm{F}$ & 0.775 & 2.88 \\
\hline & Helianthus rigidus & $\mathrm{F}$ & 0.775 & 2.88 \\
\hline & Monarda fistulosa & $\mathrm{F}$ & 2.33 & 4.81 \\
\hline & Agropyron caninum & G & 0.775 & -- \\
\hline & Schizachyrium scoparium & G & 0.775 & -- \\
\hline & Stipa comata & $\mathrm{G}$ & 0.775 & -- \\
\hline & Amorpha canescens & $\mathrm{S}$ & 2.33 & -- \\
\hline & Symphiocarpos occidentalis & $S$ & 7.75 & - \\
\hline & Carex eleocharis & G & -- & 5.77 \\
\hline & Carex heliophila & G & -- & 9.62 \\
\hline & Dicanthelium wilcoxianum & G & _- & 0.962 \\
\hline & Achillea millefolium & $\mathrm{F}$ & -- & 0.962 \\
\hline & Anemone cylindrica & F & -- & 8.65 \\
\hline & Artemisia ludoviciana & $\mathrm{F}$ & -- & 2.88 \\
\hline & Asclepis viridis & $\mathrm{F}$ & -- & 3.85 \\
\hline & Aster ericoides & $\mathrm{F}$ & -- & 1.92 \\
\hline & Astragalus flexиosus & $\mathrm{F}$ & -- & 0.962 \\
\hline & Cirsium flodmanni & $\mathrm{F}$ & -- & 0.962 \\
\hline & Equisetum laevigatum & $\mathrm{F}$ & -- & 1.92 \\
\hline & Geum triflorum & $\mathrm{F}$ & -- & 0.962 \\
\hline & Lactuca oblongifolia & $\mathrm{F}$ & -- & 10.6 \\
\hline & Lithospermum canescens & $\mathrm{F}$ & -- & 0.962 \\
\hline & Ratibida columnifera & $\mathrm{F}$ & -- & 1.92 \\
\hline & Solidago mollis & $\mathrm{F}$ & -- & 0.962 \\
\hline & Viola pedata & $\mathrm{F}$ & -- & 0.962 \\
\hline \multirow{25}{*}{24} & Agropyron caninum & G & 0.481 & 0.565 \\
\hline & Bromus inermis & G & 20.2 & 11.3 \\
\hline & Poa pratensis & G & 47.1 & 11.3 \\
\hline & Stipa spartea & G & 3.37 & 1.69 \\
\hline & Anemone cylindrica & $\mathrm{F}$ & 0.481 & 2.26 \\
\hline & Artemisia frigida & $\mathrm{F}$ & 0.481 & 2.82 \\
\hline & Artemisia ludoviciana & $\mathrm{F}$ & 1.92 & 7.91 \\
\hline & Galium boreale & $\mathrm{F}$ & 6.25 & 9.04 \\
\hline & Helianthus rigidus & $\mathrm{F}$ & 11.1 & 10.7 \\
\hline & Solidago canadensis & $\mathrm{F}$ & 0.481 & 2.26 \\
\hline & Solidago mollis & $\mathrm{F}$ & 0.962 & 3.39 \\
\hline & Amorpha canescens & $S$ & 1.44 & -- \\
\hline & Symphiocarpos occidentalis & $\mathrm{S}$ & 5.77 & -- \\
\hline & Carex eleocharis & G & -- & 4.52 \\
\hline & Carex heliophila & $\mathrm{G}$ & -- & 4.52 \\
\hline & Stipa comata & G & -- & 0.565 \\
\hline & Achillea millefolium & $\mathrm{F}$ & -- & 0.565 \\
\hline & Androsace occidentalis & $\mathrm{F}$ & -- & 5.08 \\
\hline & Aster ericoides & $\mathrm{F}$ & -- & 6.21 \\
\hline & Astragalus flexuosus & $\mathrm{F}$ & -- & 3.39 \\
\hline & Comandra umbellata & $\mathrm{F}$ & -- & 5.08 \\
\hline & Solidago missouriensis & $\mathrm{F}$ & -- & 0.565 \\
\hline & Melilotus officinalis & $\mathrm{F}$ & -- & 1.69 \\
\hline & Potentilla hippiana & $\mathrm{F}$ & -- & 0.565 \\
\hline & Psoralea argophylla & $\mathrm{F}$ & -- & 3.95 \\
\hline \multirow[t]{9}{*}{29} & Agropyron caninum & G & 35.8 & 31.3 \\
\hline & Poa pratensis & G & 60.6 & 31.3 \\
\hline & Equisetum laevigatum & $\mathrm{F}$ & 1.21 & 4.69 \\
\hline & Onosmodium molle & $\mathrm{F}$ & 1.21 & 1.56 \\
\hline & Trifolium repens & $\mathrm{F}$ & 1.21 & 3.13 \\
\hline & Carex spp. & G & -- & 1.56 \\
\hline & Oxalis stricta & $\mathrm{F}$ & -- & 14.1 \\
\hline & Euphorbia glyptosperma & $\mathrm{F}$ & -- & 10.9 \\
\hline & Artemisia ludoviciana & $\mathrm{F}$ & -- & 1.56 \\
\hline
\end{tabular}

${ }^{1} \mathrm{~F}=$ forb, $\mathrm{G}=$ graminoid, $S=$ shrub 


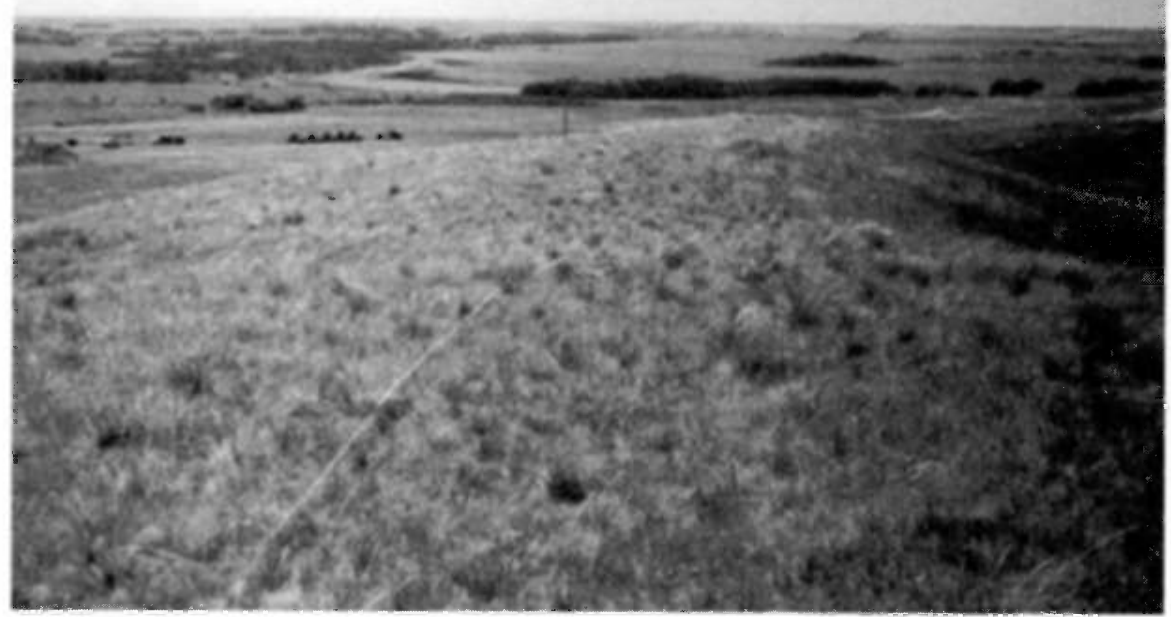

Photo 3. Bouteloua gracilis-Stipa spp. community at Camp Grafton South.

shift in species composition early enough to avoid significant short-term and longterm environmental impacts on natural resources. Other sampling methods may be necessary to detect shifts in species composition towards a less desirable plant community or decreases in biodiversity that may result from heavy land-use.

\section{Literature Cited}

Barker, W.T. and W.C. Whitman. 1989. Vegetation of the northern Great Plains. N. Dak. Agr. Exp. Sta. Res. Rep. 111 pp. Fargo, N.D

Barker, W.T., K.K. Sedivec, C.W. Prosser, C. Slaughter, G. Yanzter, N. Jacobson, and D. Anderson. 1998. Camp Grafton Integrated Natural Resource Management Plan (INRMP). Gov't Rept., North Dakota National Guard, Fraine Barricks, Bismarck, N.D.

Biondini, M.E., A.A. Steuter, and C.E. Grygiel. 1989. Seasonal fire effects on the diversity patterns, spatial distribution and community structure of forbs in the Northern Mixed Prairie, USA. Vegetatio 85:21-31.

Bonham, C.D. 1989. Measurements for terrestrial vegetation. John Wiley \& Sons, Inc. N.Y., N.Y.

Brady, W.W., J.E. Mitchell, C.D. Bonham, and J.W. Cook. 1995. Assessing the power of the point-line transect to monitor changes in plant basal cover. J. Range Manage. 48: 187-190.

CEMML (Center for Environmental Management of Military Lands.) 2001. Vegetation Measurement Methods Comparison. www.cemml.colostate.edu/methods/methods.htm (Accessed Feb. 12, 2001.)
Daubenmire, R.F. 1959. Canopy coverage method of vegetation analysis. Northwest Sci. 33:43-64.

Dekeyser, E.S. 1995. Vascular flora of Camp Grafton South in Eddy County, North Dakota. Master's Thesis, North Dakota State Univ., Fargo, N.D.

Diersing, V.E., R.B. Shaw, and D.J. Tazik. 1992. US Army Land Condition-Trend Analysis (LCTA) Program. Environ Manage. 16(3): 405-414.

Goodall, D.W. 1952. Some considerations in the use of point quadrats for the analysis of vegetation. Aust. J. Scientific Res., Series B $5: 1-41$.

Goodall, D.W. 1953. Point-quadrat methods for the analysis of vegetation. Aust. J. Botany $1: 457-461$.

Goran, W. D., L.L. Radke, and W.D. Severinghaus. 1983. An overview of the ecological effects of tracked vehicles on major U.S. Army installations. U.S. Army Construction Engineering Research Laboratory Technical Report N-142. Champaign, Ill: U.S. Army CERL.

Great Plains Flora Association. 1986. Flora of the Great Plains. Univ. Press of Kansas. $1392 \mathrm{pp}$

Joern, A. and K.H. Keeler (eds.). 1995. The Changing Prairie: North American Grasslands. Oxford Univ. Press, N.Y.

Küchler, A.W. 1964. Potential natural vegetation of the conterminous United States Amer. Geog. Soc. Spec. Pub. 36. 116 pp.

Levy, E.B. and E.A. Madden. 1933. The point method of pasture analysis. N.Z. J. Agr. 46:267-279.

Mack, R.N. 1981. Invasions of Bromus tectorum L. into western North America: an ecological chronicle. Agroecosystems. 7:145165

Milchunas, D.G., K.A. Schulz, and R.B. Shaw. 2000. Plant community structure in relation to long-term disturbance by mecha- nized military maneavers in a semi arid region. Environ. Manage. 25:525-539.

Mueller-Dombois, D. and H. Ellenberg. 1974. Aims and methods of vegetation ecology. John Wiley and Sons, Inc. New York, N.Y.

National Research Council. 1994. Rangeland health: new methods to classify, inventory, and monitor rangelands. Committee on Rangeland Classification, Board of Agriculture. Nat. Acad. Press, Washington, D.C.

NOAA (National Oceanic and Atmospheric Administration). 1995-1997. Climatological data, North Dakota: Monthly data and annual summaries for 1995-1997. National Climatic Center, Ashville, N.C.

North Dakota Outdoors. 1986. The Rare Ones. Official publication of the North Dakota State Game and Fish Dept., Bismarck, N.D. Vol. XLIX, No. 2.

Price, D.L, A.B. Anderson, W.R. Whitworth, and P.J. Guertin. 1995. Land Condition Trend Analysis Data Summaries. USACERL Tech Rpt. 95/39.

Randall, J.M. 1996. Weed control for the preservation of biological diversity. Weed Tech. 10:370-383.

Skinner, K.M. 1995. Plant and grasshopper community composition: indicators and interactions across three spatial scales. M.S. Thesis, Montana State Univ., Bozeman, Mont.

Stohlgren, T.J., K.A. Bull, and Y. Otsuki. 1998. Comparison of rangeland vegetation sampling techniques in the Central Grasslands. J. Range. Manage. 51:164-172.

Tazik, D.J., S.D. Warren, V.E. Diersing, R.B. Shaw, R.J. Brozka, C.J. Bagley, and R.W. Whitworth. 1992. USARMY Land Condition - Trend Analysis (LCTA) Plot Inventory Field Methods. USACERL Tech. Report N-92/03.

USALIAC (U.S. Army Land Inventory Advisory Committee.) 1989. Report of LCTA Review. 6 pp.

U.S. Department of the Army. 1978. Training lands: Unit training land requirements Training Circular 25-1. Headquarters Dept. of the Army, Washington, D.C.

U.S. Department of the Army. 1989. Facilities Engineering and Housing Annual Summary of Operations--Fiscal Year 1989. Office of the Assistant Chief of Engineers, U.S. Army Engineering and Housing Support Center.

U.S. Department of Interior, Fish and Wildlife Service. 1973. Threatened wildlife of the United States. Resource Publication 114. $289 \mathrm{pp}$.

U.S. GAO (General Accounting Office.) 1991. Rangeland management: Forest Service not performing needed monitoring of grazing allotments. GAO/RCED-91-148. Washington, D.C.

Whitman, W.C. and W.K.Wali, 1975. Prairie: A multiple view. Univ. North Dakota Press, Grand Forks, N.D. p. 53-73.

Wolff, R.D. 1990. Army land inventory and monitoring procedures on military installations. CEHSC-FN Technical Note 420-74-3. 